\title{
BIBLIOGRAFIJA LJUBOV VIKTOROVNE KURKINE
}

0 V bibliografijo zajeta dela so izšla v letih 1964-2017. Razvrščena so v štiri razdelke: (1) monografije, (2) razprave in članki, (3) recenzije, (4) poročila. V posameznih razdelkih so objave združene pod letnicami izida, ki so v bibliografskem podatku natisnjene polkrepko, v okviru istega leta pa si objave sledijo po azbučnem zaporedju ciriličnih in nato po abecednem zaporedju latiničnih naslovov knjig, zbornikov in revij. - Za naslovom razprav ali člankov so v oglatih oklepajih zapisani obravnavani leksemi, ki prvotno niso bili združeni v podnaslov; že v prvotni objavi v podnaslov združeni so zapisani v okroglih oklepajih ali pa pred njimi stoji dvopičje. - Spletne povezave so bile dostopne 8. 1. 2018.

\section{MonografiJe}

1 Этимологический словарь славянских языков: праславянский лексический фонд1 1-40-, Москва: Наука, 1974-2016-. - Uredniki: zv. 1-31 O. N. Trubačov, zv. 32 O. N. Trubačov in A. F. Žuravljov, zv. 33-39 A. F. Žuravljov, zv. 40 A. F. Žuravljov in Ž. Ž. Varbot. - V vseh izšlih zvezkih je bila L. V. Kurkina zadolžena za izbor, obdelavo in sistematizacijo gradiva bolgarskega, makedonskega, starocerkvenoslovanskega in slovenskega jezika, od zvezka 40 dalje tudi gradiva poljskega jezika. Natančna evidenca po avtorstvu geselskih sestavkov je bila uvedena šele v zvezku 14. - Avtorstvo L. V. Kurkine po zvezkih:

14, 1987, 200-213

$\mathbf{1 5}, 1988,32-75$

16, 1990, 75-118

17, 1990, 130-183

18, 1993, 160-219

19, 1993, 69-115, 172-185

20, 1994, 121-146

21, 1994, 7-17, 140-184

22, 1995, 246-255

1 Этимологический словарь славянских языков 〈http://etymolog.ruslang.ru/index. php?act=essja $\rangle$. 
23, 1996, 5-86

24, 1997, 56-91, 151-234

25, 1999, 5-19, 40-54, 202-238

26, 1999, 7-19

27, 2000, 97-160

28, 2001, 67-107, 135-204

29, 2002, 135-154, 248-253

30, 2003, 5-70, 185-226

31, 2005, 118-142, 143, 145-146, 149, 152-188, 205-207

32, 2005, 141-224

33, 2007, 37-91, 212-284

35, 2009, 17-87

36, 2010, 115-165

37, 2011, 157, 163-214

38, 2012, 131-180

39, 2014, 166-223

40, 2016, 59-95, 164-206

2 Диалектная структура праславянского языка по данным южнославянской лексики (Narečna struktura praslovanskega jezika v luči južnoslovanske leksike), Ljubljana: Slovenska akademija znanosti in umetnosti, 1992 (Dela razreda za filološke in literarne vede 38), 260 str. 〈https://inyurl.com/narecna = http://www.sazu.si/uploads/files/57dfbe71e126b1a75cebe90f/Kurkina\%20 1992\%20--\%20Dialektnaja\%20struktura\%200CR_c\%201-pdfA.pdf $).$

3 Толковый словарь русского языка с включением сведений о происхождении слов: 82000 слов и фразеологических выражений, ред. Н.Ю. Шведова, Москва: Институт русского языка им. В.В. Виноградова РАН (izd.) - Москва: Азбуковник (zal.), 2007, 1164 str. - Avtorica etimoloških razdelkov gesel z iztočnicami, ki so slovanskega izvora, stare izposojenke ali izposojenke iz časa do 18. stoletja, je L. V. Kurkina, avtor etimoloških razdelkov z iztočnicami, ki so izposojenke iz časa od 18. do 20. stoletja, pa L. P. Krisin. - Dotis: 2008, 2011.

4 Культура подсечно-огневого земледелия в зеркале языка, Москва: Азбуковник, 2011, 368 str.

5 Литература кучебному курсу «Этимология» (применително крусскому языку), [2011], 38 str. 〈http://etymolog.ruslang.ru/doc/etymology_literature. pdf $\rangle$.

\section{RAZPRAVE IN ČLANKI}

6 К вопросу о поведении сонантов в некоторых группах глаголов в славянских языках, Вестник Московского государственного университеma: филология, журналистика 1964, št. 3, 71-75. 
7 О некоторых поздних образованиях в системе славянских глаголов на $-i$, Этимология [1964]:2 принципь реконструкиии и методика исследования, Москва: Наука, 1965, 44-55.

8 О типах отношений основ на $-i$ и $-n Q$ в славянских языках, Этимология 1965: материалы и исследования по индоевропейским и другим языкам, Москва: Наука, 1967, 140-152.

9 Варакать, Этимология 1965, Москва: Наука, 1967, 184-188.

10 Словенские этимологии [bezati, bohôt], Этимология 1966: проблемь лингвогеографии и межъязыковых контактов, Москва: Наука, 1968, 105-106.

11 Названия болот в славянских языках, Этимология 1967: материаль международного симпозиума «Проблемы славянских этимологических исследований в связи с общей проблематикой современной этимологии» 24-31 января 1967 г., Москва: Наука, 1969, 129-144.

12 Из наблюдений над некоторыми названиями дорог и тропинок в славянских языках, Этимология 1968, Москва: Наука, 1971, 92-105.

13 Словенско-восточнославянские лексические связи, Этимология 1970, Москва: Наука, 1972, 91-102.

14 К сравнительной характеристике лексического состава южнославянских языков, v: Кузнецовские чтения: история славянских языков и письменности, Москва, 1973, 17-18.

15 К реконструкции этимологических связей основ с дифтонгом на -u, Этимология 1971, Москва: Наука, 1973, 58-79.

16 Славянские этимологии [укр. nixyp, словен. smogor, voleki, ribast, *ręb-/ *rqb-, *pel-/*pelv-, skólke, čûžje], Этимология 1971, Москва: Наука, 1973, 87-92.

17 Этимологические заметки [праслав. *mъrdati, чеш. mrskati, pyc. мырить], Общеславянский лингвистический атлас: материаль и исследованияз 1972, Москва: Наука, 1974, 215-223.

18 Славянские этимологии II [русск. пе́mamb, слав. *muz(g)ati, *luzgati/ *lyzgati, укр. pепатися, словен. lohnẹti, lẹ́hniti, kvŕga], Этимология 1972, Москва: Наука, 1974, 60-80.

19 Славянские этимологии III [слав. *-moliti, праслав. *drъmati, с.-хорв. róziti se, праслав. *lěviti], Этимология 1973, Москва: Наука, 1975, 34-43.

20 Изоглоссные связи южнославянской лексики (материалы к проблемам славянского этногенеза), v: Вопросы этногенеза и этнической истории славян и восточных романцев, Москва: Наука, 1976, 129-155.

21 Этимология болг. ръся, Общеславянский лингвистический атлас: материальл и исследования 1974, Москва: Наука, 1976, 132-136.

2 Этимология $\langle\mathrm{http}: /$ etymolog.ruslang.ru/index.php?act=contents\&book=etymology.

3 Общеславянский лингвистический атлас: материальы и исследования 〈http://www. slavatlas.org/publications.html . 
22 Этимологические заметки [русск. тормошить, словен. otrkniti, укр. ле́ста, стрибати, словен. rášiti, слав. *rešeto, в.-луж. skomorić, словен. trâbje], Этимология 1974, Москва: Наука, 1976, 44-59.

23 Славянские этимологии IV (словен. škrt, с.-хорв. pr̈titi, слав. *strukъ/ *strqkb), Этимология 1975, Москва: Наука, 1977, 13-28.

24 Заметки по словенской этимологии [pléhek, stŕniti, krke, ušti, kávrna, prprica, snóga, zaróžen], Общеславянский лингвистический атлас: материаль и исследования 1976, Москва: Наука, 1978, 278-293.

25 Изоглоссные связи южнославянской лексики II, Этимология 1976, Москва: Наука, 1978, 17-31.

26 Заметки по славянской этимологии [слав. *̌̌čbvati, *̌šcujo, с.-хорв. oklijèvati, čapońak], Общеславянский лингвистический атлас: материаль и исследования 1977, Москва: Наука, 1979, 285-294.

27 Названия горного рельефа (на материале южнославянских языков), Этимология 1977, Москва: Наука, 1979, 39-54.

28 Словенско-западнославянские лексические связи, Общеславянский лингвистический атлас: материалы и исследования 1978, Москва: Наука, 1980, 331-338.

29 Славянские этимологии [*-krějo, *krbjati, *perkъ/*pbrkъ, *(s)karati, слав. *slopbcb], Этимология 1978, Москва: Наука, 1980, 32-37.

30 Заметки по болгарской этимологии [во̀рбъ, ко̀пра се, раскр̀̀ства се, то́влем, трѝта, штинѐu, шл'акам, шю́дравый], Этимология 1978, Москва: Наука, 1980, 38-43.

31 Некоторые вопросы формирования южных славян в связи с паннонской теорией Е. Копитара, Вопросы языкознания4 1981, št. 3, 85-97.

32 Славянские этимологии [*še-mbrěti, *sko-vbrěti, *ša-vbrěti, *skomud-/ *ščemъd-, *sko-vbrga, *šebol-], Общеславянский лингвистический атлас: материаль и исследования 1979, Москва: Наука, 1981, 331-337.

33 Заметки по русской диалектологии (изнахрятиться, изляк, клопик, сморжки, зябь), v: Этимологические исследования, Свердловск, 1981, 133-137.

34 Праславянские лексические диалектизмы южнославянских языков [ю.-слав. *mъrsiti, *šupъ, šuplb, словен. kópiti, miljâva, snúditi se, vada, végati, vézniti, болг. отчер, шикълкъ, макед. шќебав, с.-хорв. оš́́ela, škĭge], Этимология 1979, Москва: Наука, 1981, 15-28.

35 Заметки по словенской этимологии [obrúten, preonêgati, pákelj, pakóta, rúgati se, sklabotína, str̂̌z̆], Общеславянский лингвистический атлас: материаль и исследования 1980, Москва: Наука, 1982, 275-281.

36 Лексические архаизмы родопского диалекта, Этимология 1980, Москва: Наука, 1982, 16-30.

4 Вопросы языкознания 〈http://www.ruslang.ru/vopjaz_archive $\rangle.$ 
37 Славянские этимологии: *korda, *moldzjb, *pelti, *peljo и *pelti, *pelvo, Этимология 1981, Москва: Наука, 1983, 3-16.

38 Лексические изоглоссы болгарского языка, v: Die slawischen Sprachen 2, Salzburg, 1983, 35-42.

39 Славянские этимологии [*krek-/*krok-, *sold-/*sbld-], Общеславянский лингвистический атлас: материаль и исследования 1981, Москва: Наука, 1984, 282-291.

40 Нарощить. Ремезить. Дьмьей, Этимологические исследования, Свердловск, 1984, 74-79.

41 Значение данных староболгарской письменности для реконструкции и этимологизации праславянского лексического фонда, Palaeobulgarica (София) 8 (1984), št. 2, 3-13.

42 Праславянские диалектные истоки южнославянской языковой группы, Вопросы языкознания 1985, št. 4, 61-71.

43 Неуклюсик. Опрудать, опрудить. Полкать. Сныч, v: Диалектография русского языка, Москва: Наука, 1985, 184-189.

44 Этимологические заметки [*kruliti, *tuskati/*tyskati], Общеславянский лингвистический атлас: материаль и исследования 1982, Москва: Наука, 1985, 281-285.

45 Южнославянские этимологии (*kujati/*kaviti и *kbvati/*kyvati; *mug-/ *mъž-; *plesmo, *ob-pletz; *pokati, *počiti/*pęčiti; *kujb, *kuja; *tulb, *tylb, *tvelb), Этимология 1982, Москва: Наука, 1985, 13-24.

46 Славянские этимологии (*luna/*lun'a, *setbnъjь и *sotiti, *stopbnъkъ, *telm-/*tolm-/*tblm-, *trek-/*trok-/*trak-, *tronъka, *zobblb), Этимология 1983, Москва: Наука, 1985, 20-30.

47 К реконструкции праславянского лексического фонда словенского языка, Этимология 1984, Москва: Наука, 1986, 107-115.

48 К проблеме словенско-западнославянских языковых связей, v: Античная балканистика, Москва, 1987, 61-67.

49 Пар. Патрать. Стиг. Притчеватый. Понки, v: Русские диалекты:: лингвогеографический аспект, Москва: Наука, 1987, 204-208.

50 Вариантность основ на $-i$, -о и - $а$ в южнославянских языках, v: Conoставительное изучение словообразования славянских языков, ред. Г.П. Нещименко, Москва: Наука, 1987, 164-169.

51 Этимология в историческом словаре, v: Историческая лексикология и лексикография русского языка: методические материаль, Вологда, 1988, 16-17.

52 Словенские этимологии [kŕzma, štrẹkelj, osmléda, oščévati], Общеславянский лингвистический атлас: материаль и исследования 1983, Москва: Наука, 1988, 297-304.

53 Слав. *terbuxъ/*tьrbuхъ, Общеславянский лингвистический атлас: материаль и исследования 1984, Москва: Наука, 1988, 273-277. 
54 Этимологии русских диалектных слов (русск. польга́листый, оха́верник, пакоруко́й), Этимологические исследования, Свердловск, 1988, 66-68.

55 Славянские этимологии (*-smegnoti/*-smegnoti, *marati, *o(b)poka), Эmuмология 1985, Москва: Наука, 1988, 10-16.

56 Словенские этимологии [mólnjen, súsati, vrétje], Общеславянский лингвистический атлас: материаль и исследования 1985-1987, Москва: Наука, 1989, 263-265.

57 Славянские этимологии [словен. opésniti, stênj, слав. *madežb], Этимология 1986-1987, Москва: Наука, 1989, 71-78.

58 Лексические архаизмы словенского языка, v: Zbornik razprav iz slovanskega jezikoslovja: Tinetu Logarju ob sedemdesetletnici, zbral in uredil Franc Jakopin, Ljubljana: Slovenska akademija znanosti in umetnosti, 1989, 129-136.

59 М. Фасмер и его этимологический словарь, Русская речь 5, Москва: Наука, 1990, 103-108.

$60 \mathrm{~K}$ проблеме карпатоукраинско-словенских лексических связей, v: Сравнительно-историческое языкознание на современном этапе: конференциия памяти В.М. Иллича-Свитыча, 6-9 февраля 1990 г.: тезисы докладов, Москва, 1990, 20-21.

61 Лексические архаизмы русских говоров Среднего Урала, v: Русская диалектная этимология: тезисы межвузовской научной конференции (10-12 октября 1991 г.), Свердловск, 1991, 20-21.

62 Щебра. Ряжь. Загызнуть. Простень, v: Современные русские говоры, Москва: Наука, 1991, 175-177.

63 Ф. Миклошич как этимолог, v: Miklošičev zbornik: mednarodni simpozij v Ljubljani od 26. do 28. junija 1991, ur. Jože Toporišič - Tine Logar - Franc Jakopin, Ljubljana: Slovenska akademija znanosti in umetnosti - Univerza v Ljubljani - Univerza v Mariboru, 1992 (Obdobja 13), 317-328.

64 Слав. *ševeliti, Wiener Slavistisches Jahrbuch 38 (1992), 227-232.

65 Словенские этимологии [motoróga, maléti, šipraka, ozîn, obŕsniti se], Общеславянский лингвистический атлас: материаль и исследования 1988-1990, Москва: Наука, 1993, 170-174.

66 О некоторых фрагментах этимологического гнезда слав. *pelti, v: Принизипь составления этимологических и исторических словарей языков разных семей: тезисы докладов конференции, 8-9 ноября 1993 2., Москва, 1993, 22-25.

67 Паннонославянская языковая общность в системе диалектных отношений праславянского языка, v: Славянское языкознание: ХІ Международный съезд славистов, Москва: Наука, 1993, 36-45.

68 Славянские этимологии (*skovorda, *pačъkati), Этимология 1988-1990, Москва: Наука, 1993, 57-62.

69 Славянские этимологии (ю.-слав. *trapъ, слав. *sěpati, *pelestz), Этимология 1991-1993, Москва: Наука, 1994, 32-45. 
70 К этимологии русских диалектных слов: русск. диал. назола, v: Филологические науки: к 100-летию со дня рождения В.В. Виноградова, ред. М.В. Ляпон, Москва: Институт русского языка им. В.В. Виноградова PAH, 1995, 278-282.

71 К этимологии болгарских диалектизмов (пuшта, хърmъ, пигаф), v: Dialectologica Slavica: сборник к 85-летию С.Б. Бернштейна, Москва: Индрик, 1995, 59-71.

72 К проблеме региональных элементов в этимологическом словаре, v: Зборник Матице српске за филологију и лингвистику (Нови Сад) 39 (1996), št. 2, 19-27.

73 Русские этимологии (дресва́, жерства́, гверста́), Общеславянский лингвистический атлас: материаль и исследования 1991-1993, Москва: Институт русского языка им. В.В. Виноградова РАН, 1996, 287-292.

74 Диалекты как источник дополнения славянских этимологических словарей, v: Русская диалектная этимология: тезисы докладов Второго научного совещзания (17-19 апреля 1996 г.), Екатеринбург: Уральский государственный университет, 1996, 27-29.

75 Слав. *plessati ( др.-русск. Plbskovъ), Славяноведение 5 (Москва) 1996, št. 1, 7-14.

76 К этимологии русск. настропалить, v: Словарь, грамматика, текст, Москва: Институт русского языка им. В.В. Виноградова РАН, 1996, 121-127.

77 Заметки по этимологии диалектных слов (на материале «Словаря русских говоров Среднего Урала») [пермянка, попресток словен. sprostî, noдpeпетить, перепаратить/перепоратить], v: Этимологические исследования 6: материаль I-II научных совещуаний по русской диалектной этимологии, Екатеринбург: Изд. Уральского университета, 1996, 27-30.

78 Паннонская теория Копитара в свете современных исследований, v: Kopitarjev zbornik: mednarodni simpozij v Ljubljani, 29. junij do 1. julij: Jernej Kopitar in njegova doba: simpozij ob stopetdesetletnici njegove smrti, ur. Jože Toporišič, Ljubljana: Filozofska fakulteta, Oddelek za slovanske jezike in književnosti - Seminar slovenskega jezika, literature in kulture - Znanstveni inštitut, 1996 (Obdobja 15), 241-248.

79 О лексических архаизмах толминского диалекта, v: Razprave drugega razreda Slovenske akademije znanosti in umetnosti XV, ur. Franc Jakopin Janez Orešnik - Jože Toporišič, Ljubljana: Slovenska akademija znanosti in umetnosti, 1996, 35-46.

80 Подсечно-огневое земледелие на Севере России, v: Доклады и сообщения 6-й научно-практической конференции «Российская деревня: история и

5 Славяноведение 〈http://inslav.ru/page/slavyanovedenie-podshivka-nomerov-1992-2012gody $\rangle$. 
современность» II: язык российской деревни: говоры, лингвофольклористика, ономастика, Москва: Энциклопедия русских деревень, 1997, 4-9.

81 Славянские этимологии [словен. strsniti se, чеш., слвц. paratiti, польск. storzyć], Этимология 1994-1996, Москва: Наука, 1997, 46-57.

82 К проблеме историко-генетической интерпретации лексических изоглосс, v: Исследования по славянской диалектологии 5: актуальные проблемы славянской лингвогеографии, Москва: Институт славяноведения PAH, 1998, 338-345.

$83 \mathrm{~K}$ реконструкции древних форм земледелия у славян, v: Славянское языкознание: ХІІ Международный съезд славистов, Краков, 1998, Москва, 1998, 381-397.

84 К этимологии русск. спорыдать, v: Слово и культура I: памяти Никитьл Ильича Толстого, Москва: Индрик, 1998, 136-142.

85 К реконструкции древних форм земледелия у славян, v: XII Międzynarodowy kongres slawistów: streszczenia referatów, Warszawa, 1998, 202-203.

86 Термины подсечно-огневого земледелия в составе праславянского словаря, v: Prasłowiańszczyzna i jej rozpad, red. Jerzy Rusek - Wiesław Boryś, Kraków: Wydawnictwo Energeia, 1998, 207-221.

87 Паннонская теория в трудах В. Облака, v: Vatroslav Oblak: mednarodni simpozij Obdobja, Ljubljana, 12. in 13. december 1996, ur. Alenka Šivic-Dular, Ljubljana: Filozofska fakulteta, Oddelek za slovanske jezike in književnosti, Center za slovenščino kot drugi/tuji jezik, 1998 (Obdobja 17), 13-21.

88 Подсека как место обитания нечистой силы, v: Кодови словенских култура 5: земљорадња, Београд, 1999, 7-14.

89 Севернорусская топонимика как источник реконструкции терминологии подсечно-огневого земледелия, v: Русская диалектная этимология: третье научное совещзание 21-23 октября 1999 г.: тезисы докладов и сообщений, Екатеринбург, 1999, 31-34.

90 К этимологии русск. деревня, v: Сельская Россия: прошлое и настоящее, Москва: «Энциклопедия русских деревень», 1999, 148-150.

91 Славянские термины подсечного земледелия на индоевропейском фоне, Балто-славянские исследования 1998-1999, Москва: Индрик, 2000, 8-23.

92 К этимологии слав. *voržiti, Јужнословенски филолог6 56 (2000), št. 1-2, 561-567.

93 Заметки по славянской этимологии [словен. râtka, ráliti, русск. диал. вй́соколить, чеш. -plasati, русск. диал. вы́прытьь, Общеславянский лингвистический атлас: материаль и исследования 1994-1996, Москва: Институт русского языка им. В.В. Виноградова РАН, 2000, 197-206.

94 Еще раз к этимологии рус. раменье, Этимология 1997-1999, Москва: Наука, 2000, 77-87.

6 Јужнословенски филолог 〈http://dais.sanu.ac.rs/handle/123456789/968〉. 
95 Понятие границы в системе пространственных представлений древних славян, v: Studia etymologica Brunensia 1: sborník př́spěvků z mezinárodní vědecké konference Etymologické symposion Brno 1999, ed. Ilona Janyšková - Helena Karlíková, Praha, 2000, 127-136.

96 К этимологии русск. диал. тимиться, v: Folia slavistica Рале Михайловне Цейтлин, Москва: Индрик, 2000, 60-64.

97 Лексические архаизмы русских говоров Среднего Урала на славянском фоне, v: Известия Уральского государственного университета: гуманитарные науки, история, филология, искусствознание 4, Екатеринбург: Издательство Уральского университета, 2001, 97-103.

98 Русская лексика как источник реконструкции пространственных представлений эпохи раннего земледелия, v: Международный конгресс исследователей русского языка: русский язык: исторические судьбы и современность: тезисы, Москва: МГУ, 2001, 74-75.

99 Лексические архаизмы архангельских говоров (по материалам «Архангельского областного словаря» вып. 1-10. М., 1980-1999 гг.), v: Языковая система и ее развитие во времени и пространстве: сборник научных статей к 80-летию проф. К.В. Горшковой, Москва: МГУ, 2001, 131-138.

100 Диалектный словарь индивидуума как один из источников лексических архаизмов русского языка, v: Аванесовский сборник, Москва: Наука, 2002, 194-203.

101 К этимологии слав. *prętati, Балто-славянские исследования, Москва: Индрик, 2002, 194-203.

102 Этимологии русских диалектизмов: русск. перзак, поржи́ть, бянки, v: Русская диалектная этимология: материаль IV Международной научной конференции 22-24 октября 2002 г., Екатеринбург: Издательство Уральского университета, 2002 г., 14-17.

103 К реконструкции динамики диалектных отношений на карте праславянского языка (по материалам лексики земледелия), v: Dzieje Stowian w świetle leksyki: pamięci profesora Fr. Stawskiego, red. Jerzy Rusek Wiesław Boryś - Leszek Bednarczuk, Kraków, 2002, 153-159.

104 От terra inculta к terra culta: на материале лексики подсечно-огневого земледелия, Общеславянский лингвистический атлас: материаль и исследования 1997-2000, Москва: Институт русского языка им. В.В. Виноградова РАН, 2003, 50-78.

105 К этимологии слав. *xrida, Этимологические исследования 8, Екатеринбург, 2003, 18-22.

106 К этимологии словенских лексических диалектизмов [kùjaunk, plen, pomuliti se, príčen, *pristren, ubrusíti se, zbərzdà:n], Этимология 20002002, Москва: Наука, 2003, 64-77. 
107 Система пространственных представлений древних славян (по материалам лексики), Славянское языкознание: ХІІІ Международный съезд славистов, Москва: Индрик, 2003, 356-375.

108 К этимологии русских диалектизмов, v: Слово в его истории и функционировании: межвузовский научный сборник: памяти доктора филологических наук, профессора Башкирского государственного университета Ю.П. Чумаковой, Уфа: Башкирский государственный университет, 2003, 99-104.

109 К реконструкции этимологических связей слав. *myliti (se) 'обманывать, вводить в заблуждение', v: Studia etymologica Brunensia 2: sborník př́spěvků z mezinárodní vědecké konference Etymologické symposion Brno 2002, ed. Ilona Janyšková - Helena Karlíková, Praha: Nakladatelství Lidové noviny, 2003, 115-125.

110 Етимологични бележки (по материали от «Български етимологичен речник»), Български език 51 (2004), zv. 4, 41-45.

111 Словенско-русские лексические параллели (по материалам «Русско-словенского» и «Словенско-русского» словарей М. Хостника), v: Davorin Hostnik med Slovenijo in Rusijo: simpozij ob 150-letnici rojstva (1853-1929), Śmartno pri Litiji, 3. september 2003 = Мартин Матвеевич Хостник между Словенией и Россией: симпозиум по поводу 150-летия со дня рождения (1853-1929), Шмартно при Литии, 3 сентября 2003 г., ur. Irena Gantar Godina - Magda Breznikar, Šmartno pri Litiji: Ustvarjalno središče Breznikar, 2004, 50-55.

112 Этимологические заметки (*ščedeti, *ščuriti), Rocznik Slawistyczny 54 (2004), 46-53.

113 Славянские топонимы как отражение культуры раннего земледелия, v: Ономастика в кругу гуманитарных наук: материалы международной научной конференции, Екатеринбург, 20-23 сентября 2005, Екатеринбург: Уральский государственный университет, 2005, 252-255.

114 Заметки по этимологии русских диалектизмов (утинья́, расчибámb, pacщуеня́ть, верло́, при́хомоть, разбала́хат, копть, хуток, хь́ллка), Общеславянский лингвистический атлас: материалы и исследования 2003-2005, Москва: Институт русского языка им. В.В. Виноградова РАН, 2006, 222-228.

115 К этимологии русск. ёрить/ерить, v: Ad fontes verborum: исследования по этимологии и исторической семантике: к 70-летию Жанны Жановны Варбот, ред. А.Ф. Журавлев, Москва: Индрик, 2006, 179-185.

116 Славянские термины земледелия в контексте индоевропейских связей, v: Studia etymologica Brunensia 3: sborník př́spěvki̊ z mezinárodní vědecké konference Etymologické symposion Brno 2005, ed. Ilona Janyšková - Helena Karlíková, Praha: Nakladatelství Lidové noviny, 2006, 153-162. 
117 К реконструкции этимологических связей слав. *čajati, v: Славенска етимологија данас: зборник симпозијума одржаног од 5. до 10. септембра 2006. године, ур. Александар Лома, Београд: Институт за српски језик САНУ, 2007, 255-264.

118 Этимологические заметки по славянской лексике [слав. *šelpati, *šalbjb, рус. диал. почава́ть], Этимология 2003-2005, Москва: Наука, 2007, 108-117.

119 К этимологии слав. *orati, v: Язык как материя смысла: сборник статей к 90-летию академика Н.Ю. Шведовой, Москва: Азбуковник, 2007, $232-238$.

120 Этимологические заметки [одерень, облеч, склядь/скляд, верёха], Общеславянский лингвистический атлас: материаль и исследования 2006-2008, Москва: Институт русского языка им. В.В. Виноградова PAH, 2008, 163-169.

121 К истокам славянской социальной терминологии (Жилище и поселение как единицы социальной организации древних славян), v: Славянское языкознание: XIV Международный съезд славистов, Москва: Индрик, 2008, 322-341.

122 Русская этимологическая лексикография, v: Теория и история славянской лексикографии: научные материалы к XIV съезду славистов, Москва: Институт русского языка им. В.В. Виноградова РАН, 2008, 369-384.

123 Термины горения в контексте культуры раннего земледелия, v: Этнолингвистика.Ономастика. Этимология: международная конференция, Екатеринбург, 8-12 сентября 2009 г., ред. Е.Л. Березович и др., Екатеринбург: Издательство Уральского университета, 2009, 149-153.

124 К этимологии слав. *paxati, v: Studia etymologica Brunensia 6: sborník př́spěvků z mezinárodni vědecké konference Etymologické symposion Brno 2008, ed. Ilona Janyšková - Helena Karlíková, Praha: Nakladatelství Lidové noviny, 2009, 173-182.

125 Комментарии к IV тому «Этимологического словаря словенского словаря» Ф. Безлая, Этимология 2006-2008, Москва: Наука, 2010, 135-166.

126 К этимологии русск. потолок, Slavia 79 (2010), št. 1, 73-80.

127 К этимологии слав. *tblo, v: W stulecie Rocznika Slawistycznego: Rocznik Slawistyczny, Kraków, 1908-2008, red. M. Wojtyła-Świerzowska, Kraków: Polska Akademia Umiejętności, 2010 (Krakowskie Studia Slawistyczne I), 175-184.

128 Заметки по русской этимологии [хибара, хомут, моро́zа, хо́барь, оскоми́ла], Общеславянский лингвистический атлас: материаль и исследования 2009-2011, Москва: Институт русского языка им. В.В. Виноградова РАН, 2011, 199-204. 
129 Обзор словенских диалектных словарей, Общеславянский лингвистический атлас: материаль и исследования 2009-2011, Москва: Институт русского языка им. В.В. Виноградова РАН, 2011, 228-248.

130 Слав. *(j)utrina, v: СЛОВА •КОНЦЕПТЫ • МИФЫ: к 60-летию А.Ф. Журавлева, ред. Г.К. Венедиктов, Москва: Индрик, 2011, 203-208.

131 Лексическое единство словенского и восточнославянских языков (на материале лексики земледелия), v: Slovenica 1, Санкт-Петербург, 2011, $175-181$.

132 К этимологии слав. *oslędb, v: Славянское и балканское языкознание: палеославистика, слово и текст, редактор В.С. Ефимова, Москва: Институт славяноведения РАН, 2012, 301-307.

133 К этимологии русск. заначка, v: Человек о языке -язык о человеке: сборник статей памяти академика Н.Ю. Шведовой, ред. М.В. Ляпон, Москва: Азбуковник, 2012, 233-237.

134 Реконструкция значения в контексте древних реалий, v: Этнолингвистика. Ономастика. Этимология: материаль II Международной научной конференциии, Екатеринбург, 8-10 сентябра 2012 2. 1, Екатеринбург: Издательство Уральского университета, 2012, 192-194.

135 Заметки по этимологии славянских слов (рус. cmpeбать, слав. *pyska/ *pъsk-, pус. ýстина, велеть, ухвоить), Этимология 2009-2011, Москва: Наука, 2012, 178-188.

136 Лексические архаизмы севернорусских говоров (по материалам «Словаря говоров Русского Севера», т. 1-4), v: Язык и прошлое народа: сборник научных статей памяти чл.-корр. РАН заслуженного деятеля науки РФ, профессора А.К. Матвеева, Екатеринбург, 2012, 276-288.

137 К проблеме интерпретации лексических связей, v: Praslovanska dialektizacija v luči etimoloških raziskav: ob stoti obletnici rojstva akademika Franceta Bezlaja: zbornik referatov z mednarodnega znanstvenega simpozija v Ljubljani, 16.-18. septembra 2012, ur. Metka Furlan - Alenka Šivic-Dular, Ljubljana: Založba ZRC, ZRC SAZU, 2012, 135-149.

138 Историко-этимологический анализ семантики древнерусских слов с затемненной внутренней формой, v: Theory and Empiricism in Slavonic Diachronic Linguistics, ed. Ilona Janyšková - Helena Kralíková, Praha: Nakladatelství Lidové noviny, 2012, 181-189.

139 Русская этимологическая лексикография, v: Славянская лексикография, ред. М.И. Чернышева, Москва: Азбуковник, 2013, 424-442.

140 К реконструкции структурно-семантических отношений в системе славянских терминов земледелия, Славянское языкознание: XV Международный съезд славистов, Москва: Индрик, 2013, 87-98.

141 К этимологии слав. *sytъ (в развитие идей Ф. Миклошича), v: Miklosichiana bicentennalia: зборник у част двестоте годишњице рођења Франа Миклошича, ур. Јасмина Грковић-Мејџор - Александар Лома, Београд: 
Српска академија наука и уметности, 2013 (Посебна издања DCLXXIV), 135-143 〈http://www.sanu.ac.rs/Izdanja/ElIzdanja.aspx $\rangle$.

142 К реконструкции этимологического гнезда слав. *tomiti, Annales Universitatis Paedagogicae Cracoviensis: studia Russologica VII, Kraków: Wydawnictwo Naukowe UP, 2014, 25-36.

143 Проблема происхождения старославянского языка в трудах В. Ягича, Slavia 83 (2014), št. 6, 262-269.

144 Заметки по этимологии русских слов (захолу́стье, сычи́ще, снеть/ снить), v: Studia Borysiana: etymologica diachronica slavica: w 75. rocznice urodzin Profesora Wiestawa Borysia, red. Mariola Jakubowicz Beata Raszewska-Żurek, Warszawa: Instytut Slawistyki PAN - Fundacja Slawistyczna, 2014, 199-208.

145 Этимологические заметки по славянской лексике, v: Труды Института русского языка им. В.В. Виноградова IV: Этимология, Москва: Вест-Консалтинг, 2015, 210-229.

146 К реконструкции в славянских языках некоторых фрагментов этимологического гнезда с и.-е. *ser- 'бежать; течь', v: Этнолингвистика. Ономастика. Этимология: материалы ІІІ Международной научной конференции, Екатеринбург, 7-11 сентября 2015 г., ред. Е.Л. Березович и др., Екатеринбург: Издательство Уральского университета, 2015, 160-162.

147 Этимологические заметки на полях «Этимологического словаря старославянского языка», v: Etymological Research into Old Church Slavonic: proceedings of the Etymological Symposium Brno 2014, 9-11 September 2014, ed. Ilona Janyšková - Helena Karlíková, Praha: Nakladatelství Lidové noviny, 2015, 203-215.

148 Словенская лексика в «Этимологическом словаре славянских языков» (вып. 1-39-, М., 1974-2014-), v: Slovnica in slovar - aktualni jezikovni opis 1, ur. Mojca Smolej, Ljubljana: Znanstvena založba Filozofske fakultete Univerze v Ljubljani, 2015 (Obdobja 34), 425-431.

149 Заметки на полях диалектного словаря, v: Труды Института русского языка VIII: Общеславянский лингвистический атлас: материалы и исследования 2012-2014, Москва: Нестор-История, 2016, 143-155.

150 Историко-этимологические заметки по русской лексике, v: Язык: nоиски, факты, гипотезы: сборник статей к 100-летию со дня рождения академика Н.Ю. Шведовой, ред. А.М. Молдован и др., Москва: Лексрус, 2016, 583-593.

151 Этимологии русских лексических диалектизмов (тромо́й, заколу́ка, во́лоб), v: В созвездии слов и имен: сборник научных статей к юбилею Марии Эдуардовны Рут, ред. Е.Л. Березович и др., Екатеринбург: Издательство Уральского университета, 2017, 91-106.

152 Диалекты как источник пополнения славянских этимологических гнезд, Труды Института русского языка им. В.В. Виноградова XII: 
Диалектология, ред. А.М. Молдован, Москва: Институт русского языка, 2017, 338-347.

153 К проблеме омонимии в славянской лексике: на материале слав. *tuliti/*tulati 'бродить' и *tuliti 'прижимать; укрывать', v: Etymological Research into Czech: Proceedings of the Etymological Symposium Brno 2017, 12-14 September 2017, Brno, ed. Ilona Janyšková - Helena Karlíková - Vít Boček, Praha: Nakladatelství Lidové noviny, 2017, 249-258.

153a К этимологии некоторых славянских анатомических терминов (oddano za objavo v zborniku s simpozija Symposium Etymologicum: śladami myśli etymologicznej: $w$ stulecie urodzin wybitnego slawisty $i$ etymologa Profesora Franciszka Sławskiego, Kraków, Collegium Maius, 25-27 maja 2016 r.).

\section{RECENZIJE}

154 «Studia z Filologii Polskiej i Słowiańskiej», 5. Warszawa, 1965, Этимология 1966: проблемы лингвогеографии и межъязыковых контактов, Москва: Наука, 1968, 382-386.

155 «Славянская лексикография и лексикология», М., изд-во «Наука», 1966, Этимология 1967: материаль международного симпозиума «Проблемы славянских этимологических исследований в связи с общей проблематикой современной этимологии» 24-31 января 1967 2., Москва: Наука, 1969, 323-325.

156 Г.П. Клепикова. Славянская пастушеская терминология. Изд. «Наука». М., 1974, 256 стр., Этимология 1975, Москва: Наука, 1977, 173-175.

157 Bezlaj F. Etimološki slovar slovenskega jezika. Prva knjiga; A-J. Ljubljana, 1976, Этимология 1977, Москва: Наука, 1979, 166-172.

158 Etymologie. Herausgegeben von Rüdiger Schmitt. (Wege der Forschung. Band CCCLXXIII). Wissenschaftliche Buchgesellschaft. Darmstadt, 1977, 457 S., Этимология 1978, Москва: Наука, 1980, 185-193 (z Ž. Ž. Varbot).

159 Etymologica Brunensia. Sborník oddělení historickosrovnávací slovanské jazykovědy. Kabinet cizích jazyků ČSAV. Praha, 1978 (ротопринт), Этимология 1979, Москва: Наука, 1981, 179-182 (z Ž. Ž. Varbot).

160 Jurišić Blaž. Rječnik govora otoka Vrgade. Uspoređen s nekim čakavskim i zapadnoštokavskim govorima. II. dio. Rječnik. Zagreb, 1973; Čakavisch-deutsches Lexikon. Teil I. Von Mate Hraste und Petar Šimunović. Unter Mitarbeit und Redaktion von Reinhold Olesch. Slavistische Forschungen 25/I. Böhlau Verlag. Köln - Wien, 1979, Этимология 1980, Москва: Наука, 1982, 180-186.

161 Езиковедски проучвания. В чест на академик Владимир Георгиев. По случай седемдесет години от рождението му. София, 1980. 518, Этимология 1981, Москва: Наука, 1983, 162-168.

162 F. Bezlaj. Etimološki slovar slovenskega jezika. Knj. II: K-O. Ljubljana, 1982, 265 с., Этимология 1983, Москва: Наука, 1985, 187-192. 
163 Р. Бернар. Българистични изследвания. София, 1982, 569 с., Этимология 1983, Москва: Наука, 1985, 194-196.

164 L. Karničar. Der Obir-Dialekt in Kärnten. Vergleich mit den Nachbarmundarten von Zell/Selo und Trögern/Korte (Phonologie, Morphologie, Mikrotoponymie, Vulgonamen, Lexik, Texte), Известия Академии наук СССР: серия литературы и языка 50 (1991), št. 1, 86-89.

165 Croatica. Slavica. Indoeuropaea. Wien, 1990, 299 S. (Wiener slavistisches Jahrbuch. Ergänzungband VIII), Вопросы языкознания 1992, št. 5, 165-168.

166 Slawistyczne studia językoznawcze. Wrocław etc., 1987, Этимология 1988-1990, Москва: Наука, 1993, 185-193.

167 Македонска академија на науките и уметностите. Одделение за лингвистика и литературна наука. Прилози XIII/1. Скопје 1988, Общеславянский лингвистический атлас: материаль и исследования 1988-1990, Москва: Наука, 1993, 198-201.

168 Etymologický slovník jazyka staroslověnského 1: Úvod, zkratky: A-blagъ. Praha, 1989; 2: blagъ-dělo. Praha, 1990 г., Этимология 1991-1993, Москва: Наука, 1994, 172-174.

169 F. Bezlaj. Etimološki slovar slovenskega jezika. Tretja knjiga P-S. Dopolnila in uredila Marko Snoj in M. Furlan. Ljubljana. Založba »Mladinska knjiga«. 1995. 355 s., Вопросы языкознания 1996, št. 4, 132-137.

170 Etymologický slovník jazyka staroslověnského. Seš. 3: dělo-gospodı. Praha, 1992; seš. 4: gostb-istonǫti. Praha, 1994; seš. 5: istopiti sę-klęti. Praha, 1995, Этимология 1994-1996, Москва: Наука, 1997, 187-189.

171 F. Bezlaj. Etimološki slovar slovenskega jezika. Tretja knjiga P-S. Dopolnila in uredila Marko Snoj in Metka Furlan. Ljubljana, 1995, Этимология 1994-1996, Москва: Наука, 1997, 194-209.

172 M. Snoj. Slovenski etimološki slovar. Založila »Mladinska knjiga«. Ljubljana. 1997. 900 s., Вопросы языкознания 1998, št. 3, 165-170.

173 Symbolae slavisticae dedykowane pani profesor Hannie Popowskiej-Taborskiej: pod redakcją Ewy Rzetelskiej-Feleszko. Warszawa, 1996, 352 s., Boпросы языкознания 1999, št. 2, 128-134.

174 M. L. Greenberg. A Historical Phonology of the Slovene Language. Universitätsverlag Carl Winter. Heidelberg, 2000. 199 p., Вопросы языкознания 2003, št. 3, 143-149.

175 Словарь говоров старообрядцев (семейских) Забайкалья. Под ред. Т.Б. Юмсуновой. [...] Новосибирск, 1997. 539 с., Общеславянский лингвистический атлас: материаль и исследования 1997-2000, Москва: Институт русского языка им. В.В. Виноградова РАН, 2003, 250-254.

176 Ronald O. Richards. The Pannonian Slavic dialect of the Common Slavic Proto-Language: The View from Old Hungarian. UCLA Indo-European Studies. Vol. 2 (2003). Los Angeles Program in Indo-European Studies, 234 p., Славяноведение 2005, št. 2, 110-116. 
177 А.А. Плотникова. Этнолингвистическая география Южной Славии. Изд. «Индрик». М., 2004, 767 с., Јужнословенски филолог 61 (2005), 229-243.

178 F. Bezlaj. Etimološki slovar slovenskega jezika. Četrta knjiga Š-Ž. Avtorji gesel F. Bezlaj, M. Snoj, M. Furlan / Uredila M. Snoj, M. Furlan. Ljubljana: Založba ZRC, 2005. 494 s., Вопросы языкознания 2006, št. 6, 113-117.

179 Fr. Bezlaj. Zbrani jezikoslovni spisi. T. I-II. Uredila M. Furlan. Ljubljana, 2003. 1572 s., Этимология 2003-2005, Москва: Наука, 2007, 336-338.

180 T. Szymański. Ze studiów nad słownictwem słowiańskim. Kraków, 2003. 168 s., Этимология 2003-2005, Москва: Наука, 2007, 361-367.

181 K. Witczak. Indoeuropejskie nazwy zbóż. Łódź, 2003. 159 s., Этимология 2003-2005, Москва: Наука, 2007, 368-371.

182 Лабунец Наталья Вадимовна. Русская географическая терминология в ситуации языкового контакта. Ред. чл.-корр. РАН А.К. Матвеев. Тюмень: Изд-во Тюмен. ун-та, 2007, 180 с., Вопросы ономастики7 (Екатеринбург) 2008, št. 2 (6), 149-160.

183 Марта Бјелетић. ИСКОВРНУТИ ГЛАГОЛИ. Типови експресивних превербалних форманата (на српском и хрватском језичком материјалу). Институт за српски језик САНУ. Монографије 2. Београд, 2006, 489 с., Јужнословенски филолог 65 (2009), 445-459.

184 M. Furlan. Novi etimološki slovar slovenskega jezika. Poskusni zvezek. Ljubljana, 2013, 221 s., Труды Института русского языка им. В.В. Виноградова IV: Этимология, Москва: Вест-Консалтинг, 2015, 422-435.

185 B. Ostrowski. Białoruskie gwary Grodzieńszczyzny. Wybrany zagadnienia. Prace Instytutu języka polskiego. 140. Kraków, 2013, 272 s., Труды Института русского языка им. В.В. Виноградова VIII: Общеславянский лингвистический атлас: материаль и исследования 2012-2014, Москва: Нестор-История, 2016, 199-205.

186 M. Furlan. Prispevki k slovenski in slovanski etimologiji. Zbirka Linguistica et philologica 32. Urednica zbirke Andreja Legan Ravnikar. Založba ZRC. Ljubljana, 2016. 208 str., Slavistična revija 65 (2017), št. 3, 569-576 〈https:// srl.si/index.php?id=stevilka\&num $=324\rangle$.

186a [V tisku:] Rada Cossutta. Ribiška jezikovna in kulturna dediščina v Tržaškem zalivu in slovenski Istri. Koper, 2015, 277 s., Труды Института русского языка им. В.В. Виноградова РАН 17: Общеславянский лингвистический атлас: материаль и исследования.

7 Вопросы ономастики 〈http://www.onomastics.ru〉. 


\section{POROČILA}

187 Хроника: «Проблемы славянских этимологических исследований» (симпозиум в Москве). 25-30 января 1967, Вестник АН СССР 1967, št. 5, 91-94.

188 Хроникальные заметки [Международный симпозиум по этимологии, исторической лексикологии и лексикографии, Москва, 1984], Bопросы языкознания 1985, št. 3, 132-136 (s S. P. Mordovino).

189 Хроникальные заметки [Etymologické symposion Brno 1999], Bопросы языкознания 2000, št. 2, 156-159 (z Ž. Ž. Varbot).

190 Хроникальные заметки [Etymologické symposion Brno 2002], Bonpocbl языкознания 2003, št. 2, 153-158 (z Ž. Ž. Varbot).

191 Хроникальные заметки: Международный этимологический симпозиум [Etymologické symposion Brno 2005], Вопросы языкознания 2006, št. 2, $151-154$ (z Ž. Ž. Varbot).

192 Хроникальные заметки: Международный научный симпозиум «Славянская этимология сегодня» [Словенска етимологија данас, Београд 2006], Вопросы языкознания 2007, št. 3, 149-153 (z Ž. Ž. Varbot).

193 Хроникальные заметки: Международный этимологический симпозиум в Брно [Etymologické symposion Brno 2008], Вопросы языкознания 2008, št. 6, 152-154 (z Ž. Ž. Varbot).

194 Научная жизнь: Международный этимологический симпозиум. Брно 2011. Теория и практика в славянском диахроническом языкознании [Etymologické symposion Brno 2011], Вопросы языкознания 2012, št. 3, $150-152$ (z Ž. Ž. Varbot).

195 Научная жизнь: Этимологический симпозиум «Этимологическое исследование старославянского языка в славянской, индоевропейской и общелингвистической перспективе». Брно, 2014 [Etymologické symposion Brno 2014], Вопросы языкознания 2015, št. 3, 146-149 (z Ž. Ž. Varbot).

195a [V tisku:] Хроникальные заметки [Etymologické symposion Brno 2017], Јужнословенски филолог 2018.

Po predlogi Ljubov V. Kurkine

uredili Metka Furlan, Silvo Torkar in Peter Weiss 